\title{
Correction to: Fragranced consumer products: effects on autistic adults in the United States, Australia, and United Kingdom
}

\author{
Anne Steinemann ${ }^{1,2,3}$
}

Published online: 19 November 2018

(C) The Author(s) 2018

\section{Correction to: Air Qual Atmos Health https://doi.org/10.1007/s11869-018-0625-x}

The article Fragranced consumer products: effects on autistic adults in the United States, Australia, and United Kingdom, written by Anne Steinemann, was originally published electronically on the publisher's internet portal (currently SpringerLink) on 25 September 2018 without open access.

With the author(s)' decision to opt for Open Choice the copyright of the article changed on November 2018 to $($ ) The Author(s) 2018 and the article is forthwith distributed under the terms of the Creative Commons Attribution 4.0 International License (http://creativecommons.org/licenses/by/4.0/), which permits use, duplication, adaptation, distribution and reproduction in any medium or format, as long as you give appropriate credit to the original author(s) and the source, provide a link to the Creative Commons license and indicate if changes were made.

The original article has been corrected.

Open Access This article is distributed under the terms of the Creative Commons Attribution 4.0 International License (http:// creativecommons.org/licenses/by/4.0/), which permits unrestricted use, distribution, and reproduction in any medium, provided you give appropriate credit to the original author(s) and the source, provide a link to the Creative Commons license, and indicate if changes were made.

The online version of the original article can be found at https://oi.org/ 10.1007/s11869-018-0625-x

Anne Steinemann

anne.steinemann@unimelb.edu.au

1 Department of Infrastructure Engineering, Melbourne School of Engineering, The University of Melbourne, Parkville, Victoria 3010, Australia

2 College of Science and Engineering, James Cook University, Townsville, Queensland 4811, Australia

3 Climate, Atmospheric Sciences, and Physical Oceanography, Scripps Institution of Oceanography, University of California, San Diego, La Jolla, CA 92093, USA 